\title{
PERANCANGAN TRYOUT ONLINE BERBASIS WEB MENGGUNAKAN FRAMEWORK BOOTSTRAP PADA SMP TIRTA BUARAN
}

\author{
Munaldi \\ Teknik Informatika, Fakultas Teknik, Universitas Pamulang \\ Jl. Surya Kencana No.1 Pamulang Barat Kota Tangerang Selatan, Banten \\ Email :dosen01573@unpam.ac.id
}

\begin{abstract}
ABSTRAK
Pemilihan program studi merupakan salah satu permasalahan yang dihadapi oleh para siswa yang ingin melanjutkan ke perguruan tinggi untuk menggapai impian masing masing siswa. Banyak siswa yang merasa bingung untuk memilih program studi apa yang cocok bagi mereka. Ada banyak faktor yang menyebabkan hal tersebut, diantaranya karena adanya keinginan orang tua, kemampuan diri sendiri, cita-cita, prospek, dll. Dalam perancangan sistem ini, penulis menggunakan metode Bootstrap sebagai metode perancangan sistem tryout online pada Smp Tirta Buaran sebagai metode pembelajaran yang digunakan saat ini. Dengan kriteria dasar yang di gunakan yakni mengembangkan keterampilan siswa dan untuk memperdalam ilmu pengetahuan oleh siswa dari setiap program studi pembelajaran dan dunia teknologi informatika data yang saat ini berkembang luas yang sudah digunakan. Aplikasi sistem Tryout Online ini program studi ini dibuat dengan bahasa pemrograman berbasis web PHP dan MySQL sebagai database. Sistem yang dibangun mampu memberikan pelatihan siswa dan memperdalam ilmu pengetahuan untuk menghadapi Ujian atau UAS dan Ujian lainnya dan bisa melihat sejauh mana ilmu pengetahuan siswa siswi yang sudah di ajarkan oleh masing-masing guru. Dengan sistem ini diharapkan dapat memberikan solusi bagi siswa untuk Semangat untuk belajar dan mengambangkan daya motivasi belajar untuk menggapai impian siswa siswi yang sudah di rencanakan, di Smp Tirta Buaran tersebut dan untuk meningkatkan kualitas lulusan yang tinggi.
\end{abstract}

Kata Kunci : Try Out, Waterfall, Bootstrap, PHP

\section{PENDAHULUAN}

Salah satu upaya untuk meningkatkan kualitas lulusan dan mutu lembaga perguruan tinggi adalah dengan cara meningkatkan kualitas kinerja guru dalam proses belajar mengajar. Kualitas lembaga pendidikan ditentukan oleh minimal tiga faktor yakni mahasiswa, guru dan fasilitas sarana belajar mengajar, ketiga faktor ini saling berkaitan dan saling mendukung antara satu dengan yang lain dalam menciptakan proses belajar yang baik (Usito, 2013).

Peran guru sebagai tenaga pengajar sangat penting dalam memberikan ilmunya kepada siswa. Menurut undang undang guru nomor 14 tahun 2005, guru adalah pendidik profesional dari ilmuwan dengan tugas utama mentransformasikan, mengembangkan dan menyebarluaskan, ilmu pengetahuan, teknologi, seni budaya melalui pendidikan, penelitian dan pengabdian pada masyarakat.

Untuk memotivasi mengembangan dan meningkatkan kinerja guru dalam proses belajar mengajar dilakukan penilaian proses belajar mengajar terhadap guru dengan siswa yang memberikan penilaian dan lembaga sekolah sebagi fasilitator.

Try out online merupakan salah satu upaya yang dilakuakan oleh guru untuk mengetahui seberapa paham anak didik dalam memahami materi menggunakan komputerisasi dengan berbasis website.

SMP Tirta Buaran masih menggunakan media kertas. Dengan demikian sekolah harus mengeluarkan biaya untuk mencetak lembar tryout bagi seluruh siswa yang akan melaksanakan ujian. Padahal tryout tidak hanya dilakukan satu atau dua kali saja dengan keadaan tersebut biaya pengeluaran sekolah semakin besar. Selain masalah biaya, waktu yang dihabiskan oleh guru juga akan tersita karena guru harus mengecek satu persatu jawaban setiap siswa untuk melihat hasil dari tryoutnya, siswa juga harus menunggu lebih lama untuk melihat hasilnya (Sri,2015). 
Strategi tryout online berbasis bootstrap merupakan salah satu Strategi pembelajaran yang berbasis Website dengan keterampilan yang baru dengan fiture yang menarik. Strategi ini juga membuat anak menjadi fokus sehingga terjadi pemahaman yang mendalam seperti atau struktur organisasi. Dalam pembelajaran ini siswa dituntut untuk peran aktif di website tersebut untuk mengikuti macam macam pelajaran yang ada di tryout tersebut.

Suatu proses pembelajaran tidak lengkap jika tidak disertai dengan evaluasi. Hasil evaluasi merupakan indikator keberhasilan terhadap pembelajaran terhadap pengajar dan peserta didiknya. Hal ini berlaku pada suatu kelas pembelajaran, tingkat sekolah, tingkat kabupaten/kota sampai tingkat nasional. Hasilnya menggambarkan tingkatan yang diwakilinya. Saat ini evaluasi yang dilakukan secara nasional untuk melihat ketercapaian pendidikan nasional adalah Ujian Nasional (UN) dalam bentuk tes objektive. Saat ini pelaksanaannya pro kontra apalagi UN dijadikan sebagai penentu kelulusan. Saya tidak bermaksud ikut berpolemik apakah UN itu diperlukan atau tidak, sepanjang belum ada konsep yang lebih matang untuk memantau pencapaian pendidikan secara nasional selain UN, maka UN itulah yang terbaik.(Jhon, 2010)

Tujuan untuk tryout online Untuk mengetahui bagaimana Sistem Tryout online dapat membantu siswa dalam melaksanakan latihan Tryout, Untuk mengetahui apakah Sistem informasi Tryout dapat meningkatkan kualitas pengetahuan siswa, Untuk mengetahui bagaimana kemudahan akses ketika menggunakan sistem informasi Tryout online.

Berdasarkan hasil observasi dan wawancara di SMP TIRTA BUARAN System tryout online ini blom di impmentasikan terhadap siswa di karnakan sosialisasi dan kurangnya tenaga kerja ahli teknologi informasi secara optimal terkadang masih dilakukan secara manual sehingga guru agak rumit untuk kalkulasi nilai dan mengoreksi jawaban dari siswa tersebut satu persatu dengan memakan waktu berhari hari ( Sri.2017)

\section{METODE PENELITIAN}

Dalam melaksanakan penelitian ini, digunakan beberapa metode sebagai berikut :

1. Observasi

Peneliti akan melakukan observasi yaitu dengan memberikan mahasiswa menelitian untuk di pahami sebagai data awal penilaian proses belajar mengajar.

2. Wawancara

Peneliti akan melakukan wawancara kepada kepala program studi untuk mendapatkan kriteria penilaian proses belajar mengajar. Dalam kegiatan ini diajukan pertanyaan lisan dalam usaha untuk melengkapi data-data yang akan diperoleh.

3. Studi Literatur

Setelah wawancara selesai maka dilakukan pengumpulan informasi dan bahan yang tepat serta memahaminya untuk digunakan dalam penerapan menunggu selesainya tahap sebelumnya dan berjalan berurutan.

Dalam penelitian ini pengembangan sistem menggunakan model waterfall tahap model waterfall adalah sebagai berikut: tahap sistem analysis, design, coding, testing, dan support/maintenance (Roger S. Pressman, 2001).

Pemodelan pengembangan sistem dengan teknik waterfall dapat di gambarkan seperti dibawah ini:

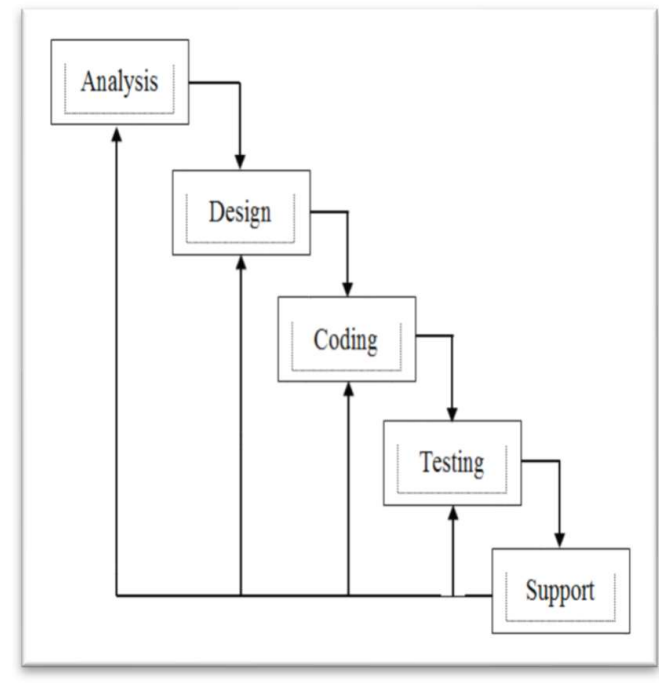

1. Analysis: bertujuan untuk mencari kebutuhan pengguna dan organisasi serta menganalisa kondisi yang ada (sebelum diterapkan sistem informasi yang baru).

2. Design: bertujuan untuk menentukan spesifikasi detil dari komponenkomponen sistem informasi (manusia, hardware, software, network dan data) dan produk-produk informasi yang 
sesuai dengan hasil tahap analisis.

3. Coding: desain program diterjemahkan ke dalam kode-kode dengan menggunaan bahasa pemrograman yang sudah ditentukan. Pada tahapan ini bertujuan untuk mengembangkan software.

4. Testing: setelah kode dihasilkan, program pengujian dimulai. Proses pengujian berfokus pada internal logis dari perangkat lunak, memastikan apakah software yang dibuat telah sesuai dengan desainnya dan masih terdapat kesalahan atau tidak, serta memastikan input yang didefinisikan akan menghasilkan hasil aktual yang sesuai dengan yang dibutuhkan.

5. Support/Maintenance: bertujuan untuk menjaga agar sistem tetap berjalan dengan produktif dan sistem dapat memiliki daya tahan selama bertahuntahun.

\section{HASIL DAN PEMBAHASAN \\ Spesifikasi Sistem}

Implementasi aplikasi diharapkan dapat memberikan kemudahan kepada pengguna aplikasi untuk mencari informasi komponenkomponen yang berada pada komputer. Berikut merupakan spesifikasi minimum perangkat pendukung untuk proses implementasi meliputi spesifikasi perangkat keras (hardware) dan perangkat lunak (software).

\section{Spesifikasi Perangkat Keras (Hardware)}

Spesifikasi perangkat keras (hardware) yang digunakan dalam implementasi merupakan spesifikasi minimum yang dapat digunakan untuk menjalankan aplikasi, spesifikasi perangkat keras (hardware) yang digunakan, yaitu :

\begin{tabular}{|c|c|c|}
\hline No & Perangkat Keras & Keterangan \\
\hline 1. & Processor & $\begin{array}{c}2.10 \mathrm{GHz} \text { processor } \\
\text { (recommended) }\end{array}$ \\
\hline 2. & Memory RAM & 2 GB of RAM (recommended) \\
\hline 3. & Memory Hardisk & 500 Gigabyte \\
\hline 4. & Monitor & Standar \\
\hline 5. & Keyboard & Standar \\
\hline 6. & Mouse & Standar \\
\hline
\end{tabular}

\section{Spesifikasi Perangkat Lunak (Software)}

Spesifikasi perangkat lunak (software) yang digunakan dalam implementasi aplikasi sistem informasi pendataan sekolah tingkat dasar yang digunakan, yaitu :

\begin{tabular}{|c|c|}
\hline Perangkat Lunak & Keterangan \\
\hline Sistem Operasi & Windows 10 32/64 bit \\
\hline Aplikasi & XAMPP, MySQL Database, \\
\hline Browser & $\begin{array}{c}\text { Google Crhome, Mozilla } \\
\text { Firefox }\end{array}$ \\
\hline
\end{tabular}

\section{Spesifikasi Antar Muka}

Spesifikasi antar muka adalah perancangan aplikasi yang telah dibuat. Berikut beberapa tampilan yang terdapat di dalam sistem informasi pendataan sekolah tingkat dasar ini :

\section{Tampilan Halaman Login}

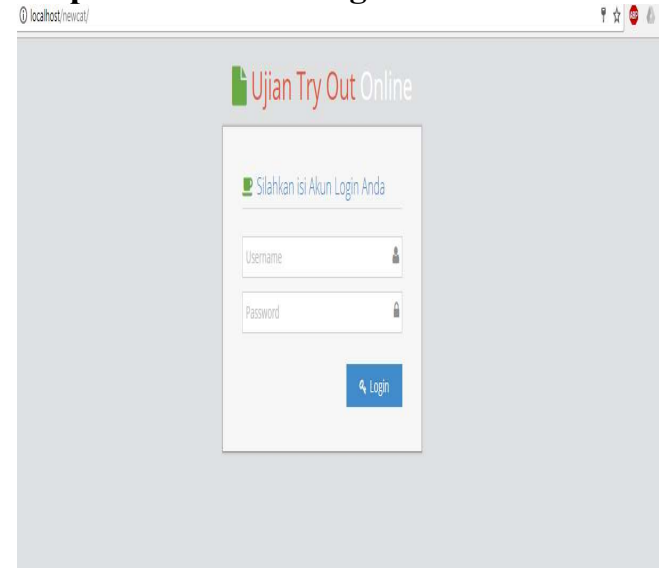

Halaman login untuk semua dari admin sampai guru dan siswa untuk masuk ke halam dashbord halaman masing masing dari guru dan siswa untuk memasukan soal dan mata pelajaran dan ujian siswa

\section{Tampilan Menu Utama}

\section{dujan Ty out online}

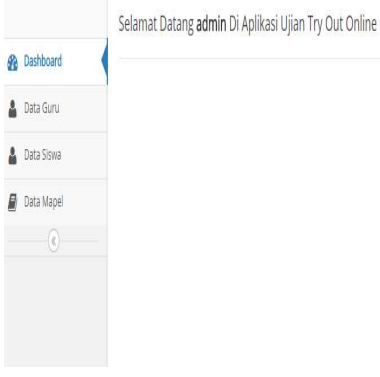

Halama Admin untuk memasukan data guru dan data siswa untuk login dan masuk ke aplikasi admin juga berperan untuk mengatur semua alur sistem untuk login guru dan siswa dan mata pelajaran 
Tampilan Menu Admin Guru

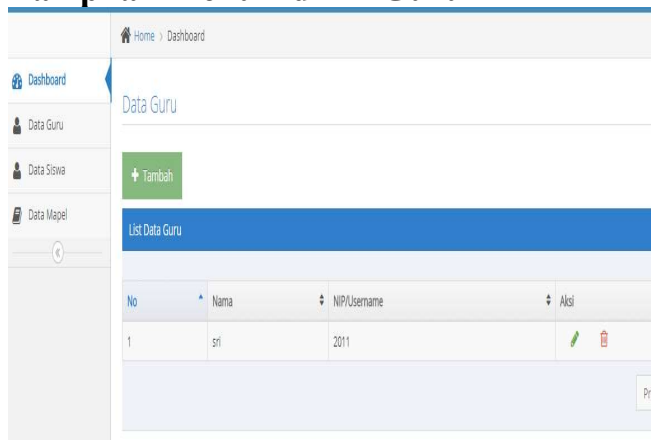

Halaman Admin untuk memasukan data guru untuk login ke halaman guru dan input soal dan ujian yang akan di ujikan

\section{Tampilan Menu Admin Siswa}

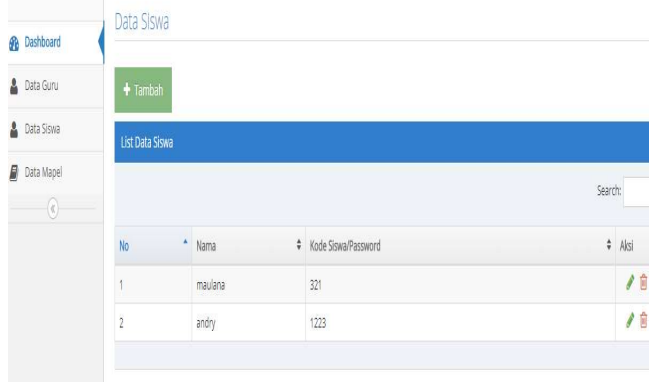

Halama Admin untuk memasukan data siswa untuk login dan masuk halaman siswa siswa pun untuk mengikuti ujian tersebut

\section{Tampilan Menu Admin Mapel}

\section{sujantryourtonine}

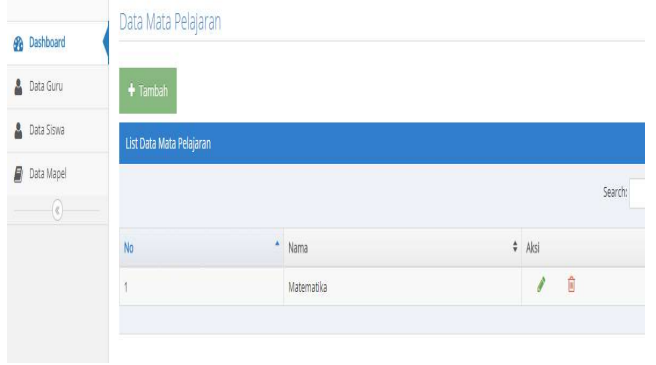

Halamaan Mapel admin berhak juga untuk input mata pelajaran untuk di ujikan kan terus terhubung dengan halaman guru dan gutu pilih ujian yang akan di ujikan

\section{Tampilan Menu Ujian Pada Guru}

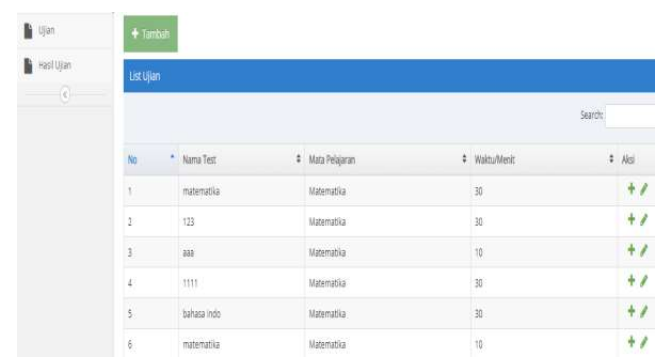

Tampilan Menu Pilih Mapel Yang Di Ujiakan Dan Waktu

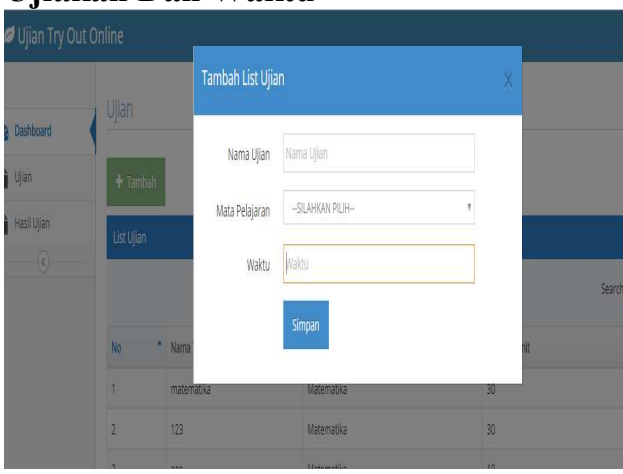

\section{Yang Di Ujiakan Dan Waktu}

Tampilan menu guru akan membuat soal ujian yang akan di ujikan dan memilih mata pelajaran dan di situ pun ada batasan waktu yang akan di ujian ke siswa

\section{Tampilan Imput Soal Pada Guru}

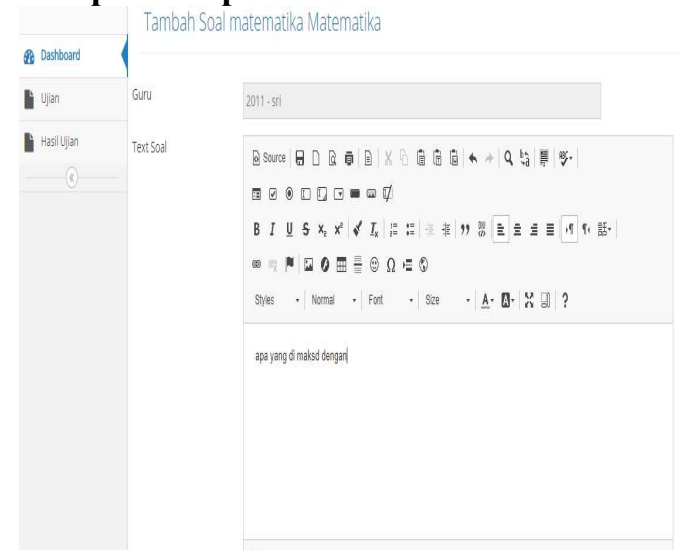

Tampilan menu guru dan guru meembuat beberapa soal dan soalnya pun secara mengacak dan siswa pun tidak bisa curang dan mencotek kesiswa lain.

Tampilan Hasil Score Siswa Setelah Ikut Tryout 


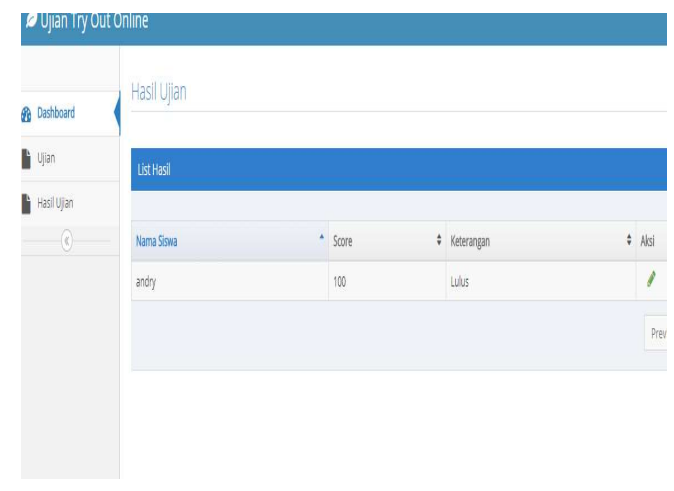

Tampilan di atas adalah hasil siswa yang sudah mengikuti ujian hasilnya pun di tampilkan dan guru juga bisa melihat letak kesalahan pada siswa pada saat pengisian soal

\section{Tampilan Soal Pada Siswa Pada Ikut Ujian} Tryout

\section{dujantryoutionine}

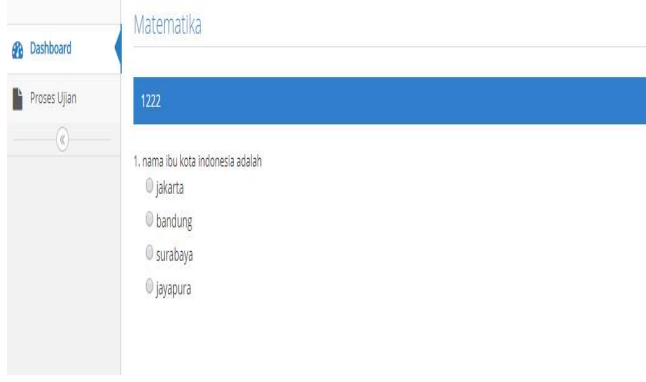

\section{Pada Siswa Pada Ikut Ujian Tryout}

Tampilan di menu siswa adalah proses tryout atau ujian yang di laksanakan oleh siswa dengan mengacak siswa pun tidak bisa curang atau mencontek stelah siswa mengisi soal akan ada tombol selesai dan siswa bisa melihat nilai siswa.

\section{Tampilan Menu Tambah Guru Pada Admin}

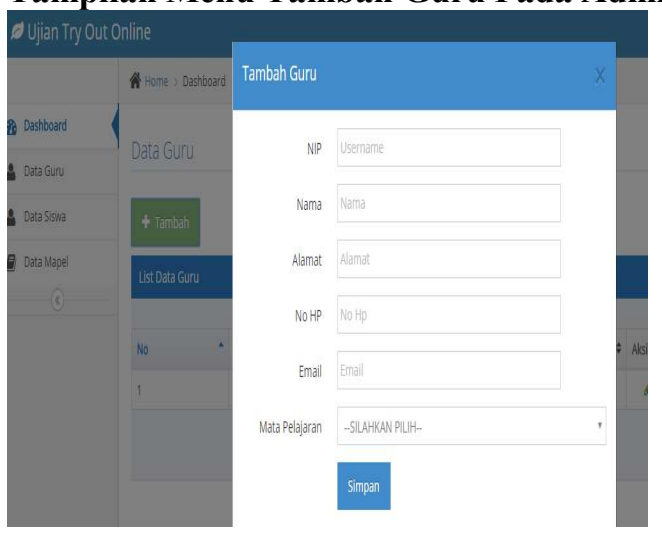

Tampilan menu menambah guru untuk login, dengan nama Nik alamat dan nomor telp dan alamat email

Tampilan Menu Tambah Siswa Pada Menu Admin

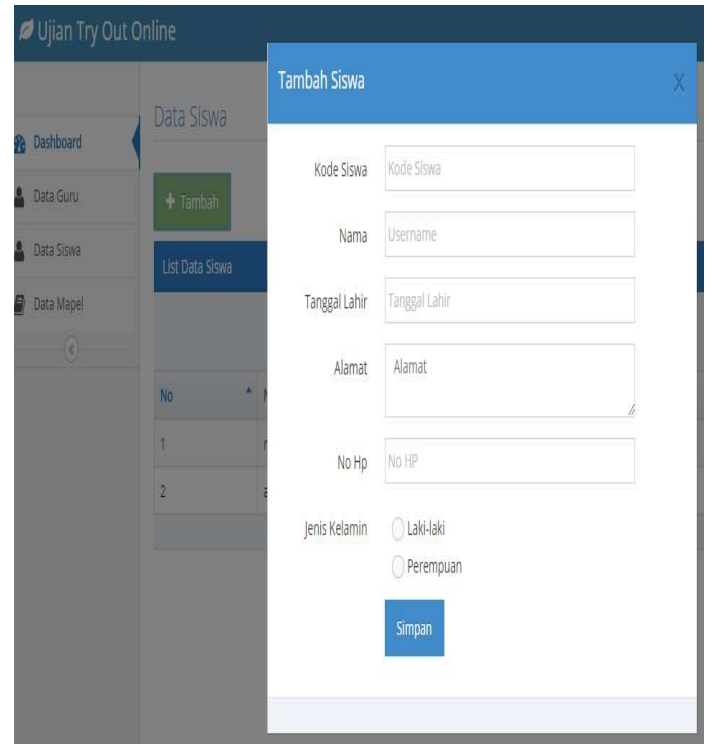

\section{Pengujian Sistem}

Pengujian sistem dilakukan dengan mencoba semua kemungkinan yang terjadi dan pengujian menggunakan pengujian black box. Jika dalam pengujian ditemukan kesalahan, maka akan dilakukan penelusuran dan perbaikan untuk memperbaiki kesalahan yang terjadi.

\section{Pengujian White Box}

White box testing yaitu metode desain test case yang menggunakan stuktur kontrol desain posedural unntuk memperoleh test case. White box sebaiknya dilakukan pada alur logika yang penting dan struktur-struktur data yang penting dapat diperoleh dengan menggunakan struktur data internal untuk menjamin validitasnya.

\section{Pengujian Black Box}

Pada tahap ini merupakan kelanjutan dari tahap implementasi yaitu melakukan pengujian terhadap aplikasi yang dibangun. Pengujian yang akan dilakukan yaitu dengan pengujian black box yang berfokus pada persyaratan fungsional perangkat lunak.

\section{Kasus dan Hasil Pengujian}

Kasus dan hasil pengujian dibuat untuk mengetahui apakah perancangan aplikasi 
sistem informasi pendataan sekolah tingkat dasar berbasis web pada UPT Kecamatan Pinang Kota Tangerang bisa berjalan dengan baik tanpa ada masalah.

\section{a) Pengujian Black Box Untuk Admin}

\begin{tabular}{|c|c|c|c|c|}
\hline No & $\begin{array}{l}\text { Skenario } \\
\text { Pengujian }\end{array}$ & $\begin{array}{l}\text { Hasil yang } \\
\text { diharapkan }\end{array}$ & $\begin{array}{c}\text { Hasil } \\
\text { pengujian }\end{array}$ & Kesimpulam \\
\hline 1 & $\begin{array}{l}\text { Memilih menu } \\
\text { login }\end{array}$ & $\begin{array}{l}\text { Menu login } \\
\text { berhasil di } \\
\text { tampilkan }\end{array}$ & Sesuai harapan & Valid \\
\hline 2 & $\begin{array}{l}\text { Memilih menu } \\
\text { dashbord }\end{array}$ & $\begin{array}{l}\text { Menu dasbord } \\
\text { berhasil di } \\
\text { tampilkan }\end{array}$ & Sesuai harapan & Valid \\
\hline 3 & $\begin{array}{l}\text { Memilih menu } \\
\text { guru }\end{array}$ & $\begin{array}{l}\text { Menu guru } \\
\text { berhasil di } \\
\text { tampilkan }\end{array}$ & Sesuai harapan & Valid \\
\hline 4 & $\begin{array}{l}\text { Menambah } \\
\text { data guru }\end{array}$ & $\begin{array}{l}\text { Data guru } \\
\text { berhasil di } \\
\text { tambahkan }\end{array}$ & Sesuai harapan & Valid \\
\hline 5 & $\begin{array}{l}\text { Memilih menu } \\
\text { siswa }\end{array}$ & $\begin{array}{l}\text { Menu siswa } \\
\text { berhasil di } \\
\text { tampilkan }\end{array}$ & Sesuai harapan & Valid \\
\hline 6 & $\begin{array}{l}\text { Menambah } \\
\text { data siswa }\end{array}$ & $\begin{array}{l}\text { Data siswa } \\
\text { berhasil di } \\
\text { tambahkan }\end{array}$ & Sesuai harapan & Valid \\
\hline 7 & $\begin{array}{l}\text { Memilih menu } \\
\text { mapel }\end{array}$ & $\begin{array}{l}\text { Data mapel } \\
\text { berhasil di } \\
\text { tampilkan }\end{array}$ & Sesuai harapan & Valid \\
\hline 8 & $\begin{array}{c}\text { Menambahkan } \\
\text { data mapel }\end{array}$ & $\begin{array}{l}\text { Data mapel } \\
\text { berhasil di } \\
\text { tambahkan }\end{array}$ & Sesuai harapan & Valid \\
\hline 9 & Klik Sign Out & $\begin{array}{c}\text { Kembali ke menu } \\
\text { utama }\end{array}$ & Sesuai harapan & Valid \\
\hline
\end{tabular}

b) Pengujian Black Box Guru

\begin{tabular}{|c|c|c|c|c|}
\hline No & $\begin{array}{l}\text { Skenario } \\
\text { Pengujian } \\
\end{array}$ & Hasil yang diharapkan & $\begin{array}{c}\begin{array}{c}\text { Hasil } \\
\text { pengujian }\end{array} \\
\end{array}$ & Kesimpulan \\
\hline 1 & $\begin{array}{c}\text { Memilih menu } \\
\text { login }\end{array}$ & $\begin{array}{c}\text { Menu login berhasil di } \\
\text { tampilkan }\end{array}$ & $\begin{array}{c}\text { Sesuai } \\
\text { harapan }\end{array}$ & Valid \\
\hline 2 & $\begin{array}{l}\text { Memilih menu } \\
\text { dashbord }\end{array}$ & $\begin{array}{c}\text { Menu dasbord } \\
\text { berhasil di tampilkan }\end{array}$ & $\begin{array}{l}\text { Sesuai } \\
\text { harapan }\end{array}$ & Valid \\
\hline 3 & $\begin{array}{c}\text { Memilih menu } \\
\text { soal ujian }\end{array}$ & $\begin{array}{c}\text { Menu ujian berhasil di } \\
\text { tampilkan }\end{array}$ & $\begin{array}{c}\text { Sesuai } \\
\text { harapan }\end{array}$ & Valid \\
\hline 4 & $\begin{array}{c}\text { Menambah menu } \\
\text { ujian }\end{array}$ & $\begin{array}{c}\text { Menu ujian berhasil di } \\
\text { tampilkan }\end{array}$ & $\begin{array}{c}\text { Sesuai } \\
\text { harapan }\end{array}$ & Valid \\
\hline 5 & $\begin{array}{c}\text { Menambah menu } \\
\text { soal }\end{array}$ & $\begin{array}{c}\begin{array}{c}\text { Menu soal berhasil di } \\
\text { tampilkan }\end{array} \\
\end{array}$ & $\begin{array}{c}\text { Sesuai } \\
\text { harapan }\end{array}$ & Valid \\
\hline 6 & $\begin{array}{c}\text { Memiliah Menu } \\
\text { hasil ujain }\end{array}$ & $\begin{array}{c}\text { Menu hasil ujian } \\
\text { berhasil di tampilkan }\end{array}$ & $\begin{array}{c}\text { Sesuai } \\
\text { harapan }\end{array}$ & Valid \\
\hline 7 & $\begin{array}{l}\text { Memilih menu } \\
\text { mapel }\end{array}$ & $\begin{array}{c}\text { Menu mapel berhasil } \\
\text { di tampilkan }\end{array}$ & $\begin{array}{c}\text { Sesuai } \\
\text { harapan }\end{array}$ & Valid \\
\hline 8 & $\begin{array}{c}\text { Menu } \\
\text { Menampilkan } \\
\text { hasil }\end{array}$ & $\begin{array}{l}\text { Menu tampilan hasil } \\
\text { berhasil di tampilkan }\end{array}$ & $\begin{array}{l}\text { Sesuai } \\
\text { harapan }\end{array}$ & Valid \\
\hline 9 & $\begin{array}{l}\text { Memilih menu } \\
\text { ujian }\end{array}$ & $\begin{array}{c}\text { Menu ujian berhasil di } \\
\text { tampilkan }\end{array}$ & $\begin{array}{c}\text { Sesuai } \\
\text { harapan }\end{array}$ & Valid \\
\hline 10 & $\begin{array}{c}\text { Menambah menu } \\
\text { ujian }\end{array}$ & $\begin{array}{c}\text { Menu ujian berhasil di } \\
\text { tampilkan }\end{array}$ & $\begin{array}{c}\text { Sesuai } \\
\text { harapan }\end{array}$ & Valid \\
\hline 11 & $\begin{array}{c}\text { Menambah menu } \\
\text { soal }\end{array}$ & $\begin{array}{c}\text { Menu soal berhasil di } \\
\text { tampilkan }\end{array}$ & $\begin{array}{c}\text { Sesuai } \\
\text { harapan }\end{array}$ & Valid \\
\hline 12 & Klik Sign Out & $\begin{array}{c}\text { Kembali ke menu } \\
\text { utama }\end{array}$ & $\begin{array}{c}\text { Sesuai } \\
\text { harapan }\end{array}$ & Valid \\
\hline
\end{tabular}

\section{c) Pengujian Black Box Siswa}

Tabel 4.1 Tabel Pengujian Black Box Siswa

\begin{tabular}{|c|c|c|c|c|}
\hline No & $\begin{array}{c}\text { Skenario } \\
\text { Pengujian }\end{array}$ & $\begin{array}{c}\text { Hasil yang } \\
\text { diharapkan }\end{array}$ & $\begin{array}{c}\text { Hasil } \\
\text { pengujian }\end{array}$ & Kesimpulam \\
\hline 1 & $\begin{array}{c}\text { Memilih } \\
\text { menu login }\end{array}$ & $\begin{array}{c}\text { Menu login } \\
\text { berhasil di } \\
\text { tampilkan }\end{array}$ & Sesuai harapan & Valid \\
\hline 2 & $\begin{array}{c}\text { Memilih } \\
\text { menu } \\
\text { dasbord }\end{array}$ & $\begin{array}{c}\text { Menu dasbord } \\
\text { berhasil di } \\
\text { tampilkan }\end{array}$ & Sesuai harapan & Valid \\
\hline 3 & Menu ujian & $\begin{array}{c}\text { Menu ujian } \\
\text { berhasil di } \\
\text { tampilkan }\end{array}$ & Susai harapan & Valid \\
\hline 4 & $\begin{array}{c}\text { Klik Sign } \\
\text { Out }\end{array}$ & $\begin{array}{c}\text { Kembali ke menu } \\
\text { utama }\end{array}$ & Sesuai harapan & Valid \\
\hline
\end{tabular}

\section{Hasil pengujian}

Pengujian pada aplikasi Perancangan Tryout Online Berbasis Bootstrap pada SMP Tirta Buara di lakukan secara black box yaitu pengujian yang di lakukan dengan hanya memperhatikan masukan ke sistem dan keluaran sistem. Dari hasil pengujian yang di lakukan dapat disimpulakan bahwa sistem sudah berjalan sepenuhnya dari apa yang di harapkan

\section{KESIMPULAN}

Kesimpulan yang dapat penulis ambil dari penelitian ini adalah :

a. Dengan adanya sistem ini siswa akan merasakan pembelajaran yang berbeda. siswa juga bisa mengakses dengan mudah cukup login dan mengikuti ujian atau aturan yang ada dan Dengan adanya web ini terbukti dapat mempermudah dalam Pembelajaran karena memuat prediksi soal yang akan keluar pada Ujian Nasional nanti.

b. Sistem ini juga akan otomatis mengacak sesuai dengan nama peserta tryout maka dari itu siswa akan lebih kosentrasi untuk mendapatkan nilai yang maksimal maka dari itu siswa memprediksi dirinya dapat kelulusan yang murni

c. Sistem ini mempunyai pengacakan dan mempunyai lembar jawaban secara otomatis dan mempunyai waktu untuk mengikuti ujian. nilai akan terhubung oleh guru tersebut dan siswa akan mengetahui sejauh mana perkembangan pembelajaran tersebut

Maka dari itu sistem ini menggunakan sistem perwaktuan pada saat ujian untuk mengatasi overload pada sistem ini dan setelah itu siswa akan mendapatkan hasil yang di ujikan

\section{DAFTAR PUSTAKA}

Adityan, A. N (2011). Jago PHP \& MySQL. Bekasi: Dunia Komputer

Ambarita, A. (2016). Analisis Pengembangan Sistem Informasi Pengolahan Aset Daerah.

Betha S,Ir. \& Husni I. P. (2014). Pemograman Wen Dengan HTML Di Sertai dari 200 contoh Program Beserta Tampilan Grafisnya.

Calam A., Andika B. \& Tanaka A.(2013) Membuka Cakrawala Dalam Program Komputer.

Zulmy, M. D. (2013). Analisis Dan Perancangan Basis Data Terdistribusi Data Inevtori Barang Pada Colombus Palembang.

Mulya, A. R. (2012). Pengembangan Sistem 
Infomasi Pelaporan dan Pengajuan Sekolah Berbasis Web.

Pressman, R. S. (2012). Rekayasa Perangkat Lunak. Yogyakarta: Andi Publisher.

Saputra, M. (2013). Perancangan Sistem Basis Data Akademik Pada SMP NEGERI 26 Palembang.

Simarmata, J. \&.(2010). Basis Data. Yogyakarta: Andi Offset.

Wahono, R. S. (2003). Pengantar Unified Modeling Language (UML). IlmuKomputer.Com.

Yakub. (2008). Sistem Basis Data Tutorial Konseptual. Graha Ilmu.

Mentari Harmadya1, Gusti Made AryaSasmita2, Ni Kadek Ayu . 2015 .. JurusanTeknologi Informasi Fakultas Teknik Universitas Udayana ./Tryout Ujian Nasional Sekolah Menengah Pertama VOL. 6, NO. 2,

Syifaun Nafisah, (2003) Pengertian Bootstrap pada Website http://www.getbootstrap.com . diakses pada 27 september 2017

De eka Sas .2013. pengertian online dan offline https://puteka85.blogspot.co.id/2013/09/men genal-perbedaan-online-dan-offline.html .

http://nafas-diri.blogspot.co.id/2012/09/pengertiandan-sejarah-bootstrap.html .

Bobby Melky Tulangow, (2011) Pengertian ujian bebasis web. STMIK PalComTech :Palembang 